\title{
Commentary: Antibodies to Human Herpesviruses in Myalgic Encephalomyelitis/Chronic Fatigue Syndrome Patients
}

\author{
Maria Eugenia Ariza ${ }^{1,2 *}$ \\ ${ }^{1}$ Department of Cancer Biology and Genetics, Wexner Medical Center, The Ohio State University, Columbus, $\mathrm{OH}$, \\ United States, ${ }^{2}$ Institute for Behavioral Medicine Research, Wexner Medical Center, The Ohio State University, Columbus, \\ $\mathrm{OH}$, United States
}

Keywords: Serology, EBV - Epstein-Barr Virus, Human herpesvirus (HHV)-6, Varicela zoster virus (VZV), Herpes Simplex virus type 1 and type 2 (HSV-1/2), Cytomegalovirus (CMV), Human herpesvirus 7 (HHV-7), Myalgic encephalomyelitis/chronic fatigue syndrome (ME/CFS)

\section{A Commentary on}

Antibodies to Human Herpesviruses in Myalgic Encephalomyelitis/Chronic Fatigue Syndrome Patients

by Blomberg, J., Rizwan, M., Böhlin-Wiener, A., Elfaitouri, A., Julin, P., Zachrisson, O., et al. (2019). Front. Immunol. 10:1945. doi: 10.3389/fimmu.2019.01946

\section{OPEN ACCESS}

Edited by:

Aurelio Cafaro,

Istituto Superiore di Sanità (ISS), Italy

Reviewed by:

Johan Van Weyenbergh,

KU Leuven, Belgium

*Correspondence:

Maria Eugenia Ariza

maria.ariza@osumc.edu

Specialty section:

This article was submitted to

Viral Immunology,

a section of the journal

Frontiers in Immunology

Received: 16 January 2020

Accepted: 01 June 2020

Published: 23 July 2020

Citation:

Ariza ME (2020) Commentary: Antibodies to Human Herpesviruses in Myalgic Encephalomyelitis/Chronic

Fatigue Syndrome Patients.

Front. Immunol. 11:1400.

doi: 10.3389/fimmu.2020.01400

\section{INTRODUCTION}

Studies to ascertain a possible relationship between herpesviruses and myalgic encephalomyelitis/chronic fatigue syndrome (ME/CFS) have relied heavily on classical approaches, specifically, serological examination for antibodies against virus proteins, primarily structural, and/or increases in viral load (1-21). These data have been conflicting due in part to several features: the heterogeneity of the disease, high prevalence of the herpesviruses in the population since they can establish lifelong infections, and differences between laboratories. Two additional problems lead to conflicting data in serological studies: which viral antigens are to be used for detection, and what is the possible relationship, if any, of these viral antigens to ME/CFS? These are important questions that must be addressed for any data to provide meaningful insight into the possible contribution of a virus to the pathophysiology of ME/CFS. Although the experimental techniques used in Blomberg's serological study were appropriate, the selection of specific herpesviruses and viral antigens studied gives a limited view of the humoral response in ME/CFS.

\section{DISCUSSION}

Blomberg et al. (22) used a suspension multiplex immunoassay to detect antibodies against various herpesviruses' antigens, derived from proteins expressed during latency or late lytic replication (Figure 1), with the goal of determining differences in antibody titers against these antigens between ME/CFS patients and controls. However, no rationale was given as to why these particular antigens were chosen and what association, if any, they may have with ME/CFS. This is important because the antigenic properties of the different virus proteins are not the same. As demonstrated in an eloquent study by Vaider-Shalt et al. (23), over the course of their evolution, herpes simplex virus 1 (HSV-1), Epstein-Barr virus (EBV), human herpesvirus 8 (HHV-8), and human 
cytomegalovirus have decreased the number of epitopes present in virus proteins in order to help them avoid immune detection. Thus, the ability of a virus protein to generate an antibody response is dependent upon the amount of protein present in the host and its antigenicity. It is also not clear why Blomberg et al. (22) included HSV-1/2, human cytomegalovirus, HHV-7, and varicella zoster virus (VZV) in their study since there are no up-to-date literature reports establishing a serological relationship between these viruses and ME/CFS.

Along these lines, measuring the response in patients' sera using purified virus lysate would only detect antibodies to proteins that are components of the virion (capsid proteins, glycoproteins, and tegument proteins) but not proteins expressed during virus lytic/abortive-lytic replication (Figure 1). Furthermore, since herpesviruses establish persistent infections in a significant proportion of the population (24), it is not surprising that antibody titers against purified virus lysates are not significantly different between ME/CFS cases and controls, especially since viremia has not been demonstrated in $\mathrm{ME} / \mathrm{CFS}$ patients. Using "crude" antigen preparations make it impossible to ascertain whether there is a difference in the formation of specific antibodies against a single protein within the two populations under study. Although the epitope mapping studies provide qualitative data, the antigens have little relevance to ME/CFS, as they focused primarily on viral proteins that are expressed either during latency in the case of $\mathrm{EBV}$ or late in the lytic replicative cycles of EBV, HHV-6A/B, and HHV-7. Several studies have demonstrated that there is no increase in viral load of EBV or $\mathrm{HHV}-6 \mathrm{~A} / \mathrm{B}$ in $\mathrm{ME} / \mathrm{CFS}$ patients $(12,14,15,17,21)$, which suggests that there is no increase in the expression of late herpesvirus proteins in $\mathrm{ME} / \mathrm{CFS}$ patients. Nor is there, in the case of EBV, an increase in viral capsid antigen (VCA) antibody titers, suggesting that abortive lytic replication is occurring in these patients (1, 17-19). Likewise, there is no evidence suggesting a role of any latency expressed gene products in ME/CFS. There is a single report showing a small non-significant difference in IgG response to Epstein-Barr nuclear antigen 3C (EBNA-3C; EBNA-6) by peptide microarray (25). EBNA-3C is the product of a gene only expressed in B cells undergoing the latency III gene-expression program, and there is no evidence to support latency type III in ME/CFS. Similarly, no rationale was provided for examining EBNA-1, although there are no studies linking it with ME/CFS. If a causal relationship is to be established between EBV, HHV-6, or any other herpesvirus and ME/CFS, it will require addressing the role of viral proteins produced during abortive-lytic replication of the herpesviruses, which does not lead to new viral progeny, and thus, no changes in viral load would be observed. Therefore, measuring humoral responses in patients' sera using virus lysate is not appropriate because it would only detect antibodies to proteins that are components of the virion but not to proteins expressed during abortive-lytic replication.

Lastly, Blomberg et al. (22) indicate in the Introduction and Discussion of their manuscript that a recent study (1) implicated VZV in ME/CFS. That is not the case. In that study, the investigators demonstrated that although ME/CFS

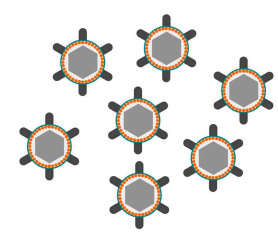

Human Herpesviruses<smiles>C=[Te]</smiles>

Purified Virus
Lysates:
- Structural
proteins and
- Tegument
proteins

Lytic/Abortive-Lytic Replication

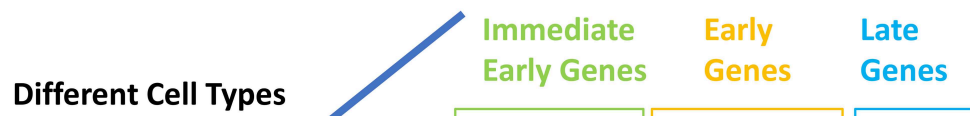

Late

(Zebra)

EBV: BZLF1

EBV: BMRF1

(EA-D)

CASCADE REGULATION of VIRUS GENE EXPRESSION

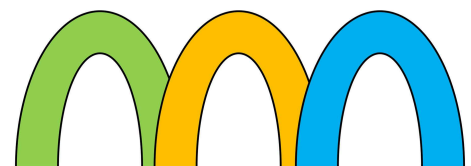

EBV: BFRF1 (VCA, p18); BALF4 (gB)

HHV-6A: U24; U39 (gB); U47 (gO); U48 (gH)

HHV-6B: U24; U39 (gB); U47 (gO); U48 (gH)

HHV-7: U11; U14; U24; U39 (gB); U98/100 (gp65)
EBNA1: Latency Programs I, II, III

EBNA2: Latency Programs III EBNA6/3C: Latency Programs III LMP1: Latency Programs II, III LMP2A: Latency Programs II, III

FIGURE 1 | Herpesviruses replication and latency programs indicating the gene/gene products tested as antigens by Blomberg et al. (22). 
patients' serum contained anti-VZV deoxyuridine triphosphate nucleotidohydrolase (dUTPase) antibodies, it was not significant $(p<0.857)$.

In conclusion, although the suspension multiplex immunoassay seems appropriate, it may lack the sensitivity of the luciferase immunoprecipitation system (26) and VirScan (27) serological platforms that have been utilized for the detection of viral infections including those caused by EBV, HSV-1, HSV-2, HHV-8, and VZV (28).

\section{REFERENCES}

1. Halpin P, Williams M, Klimas NG, Fletcher MA, Barnes Z, Ariza ME. Differential antibody patterns to the herpesviruses-encoded dUTPases in Myalgic Encephalomyelitis/Chronic Fatigue Syndrome and Gulf War Illness. J Med Virol. (2017) 89:1636-45. doi: 10.1002/jmv.24810

2. Tobi M, Morag A, Ravid Z, Chowers I, Feld-Weiss, V, Michaeli $\mathrm{Y}$, et al. Prolonged atypical illness associated with serological evidence of persistent Epstein-Barr virus infection. Lancet. (1982) 1:61-4. doi: 10.1016/S0140-6736(82)90210-0

3. DuBois RE, Seeley JR, Brus I, Sakamoto K, Ballow M, Harada S, et al. Chronic mononucleosis syndrome. Southern Med J. (1984) 77:137682. doi: 10.1097/00007611-198411000-00007

4. Buchwald D, Sullivan JL, Komaroff, AL. Frequency of chronic active Epstein-Barr virus infection in a general medical practice. $J \mathrm{Am}$ Med Assoc. (1987) 257:2303-7. doi: 10.1001/jama.1987.033901700 59028

5. Holmes GP, Kaplan JE, Stewart JA, Hunt B, Pinsky PF, Schonberger LB. A cluster of patients with a chronic mononucleosis-like syndrome. Is Epstein-Barr virus the cause? J Am Med Assoc. (1987) 257:2297302. doi: 10.1001/jama.257.17.2297

6. Hellinger WC, Smith TF, Van Scoy RE, Spitzer PG, Forgacs P, Edson, RS. Chronic fatigue syndrome and the diagnostic utility of antibody to Epstein-Barr early antigen. J. Am Med Assoc. (1988) 260:971-3. doi: 10.1001/jama.1988.03410070099036

7. Straus SE, Dale JK, Tobi M, Lawley T, Prebel O, Blaese M, et al. Acyclovir treatment of the Chronic Fatigue Syndrome. Lack of efficacy in a placebo-controlled trial. $N$ Engl J Med. (1988) 319:1692-8. doi: 10.1056/NEJM198812293192602

8. Gold D, Bowden R, Sixbey J, Riggs R, Katon WJ, Ashley R, et al. Chronic Fatigue. A prospective clinical and virologic study. J Am Med Assoc. (1990) 264:48-53. doi: 10.1001/jama.264.1.48

9. Levine PH, Jacobson S, Pocinki AG, Cheney P, Peterson D, Connelly RR, et al. Clinical, epidemiological, and virological studies in four clusters of the Chronic Fatigue Syndrome. Arch Intern Med. (1992) 152:161116. doi: 10.1001/archinte.152.8.1611

10. Manian FA. Simultaneous measurement of antibodies to Epstein-Barr virus, human herpesvirus 6 , herpes simplex virus types 1 and 2 and 14 enteroviruses in chronic fatigue syndrome: is there evidence of activation of a nonspecific polyclonal immune response? Clin Infect Dis. (1994) 19:44853. doi: $10.1093 /$ clinids/19.3.448

11. Sairenji T, Yamanishi K, Tachibaba Y, Bertoni G, Kurata, T. Antibody responses to Epstein-Barr virus, human herpesvirus 6 and human herpesvirus 7 in patients with chronic fatigue syndrome. Intervirology. (1995) 38:26973. doi: $10.1159 / 000150450$

12. Di Duca D, Zorzenon M, Mirandola P, Colle R, Botta GA, Cassai, E. Human herpesvirus 6 and human herpesvirus 7 in chronic fatigue syndrome. J Clin Microbiol. (1995) 33:1660-1. doi: 10.1128/JCM.33.6.1660-16 61.1995

13. Buchwald D, Ashley RL, Pearlman T, Kith P, Komaroff AL. Viral serologies in patients with Chronic Fatigue and Chronic Fatigue Syndrome. J Med Virol. (1996) 50:2530. doi: 10.1002/(SICI)1096-9071(199609)50:1 <25::AID-JMV6>3.0.CO;2-V

\section{AUTHOR CONTRIBUTIONS}

The author confirms being the sole contributor of this work and has approved it for publication.

\section{FUNDING}

This work was supported by the National Institutes of Health grant R01 A1084898 to MA.

14. Wallace HL, Natelson B, Gause W, Hay, J. Human herpesviruses in chronic fatigue syndrome. Clin Diagn Lab Immunol. (1999) 6:21623. doi: 10.1128/CDLI.6.2.216-223.1999

15. Reeves WC, Stamey FR, Black JB, Mawle AC, Stewart JA, Pellett, PE. Human herpesviruses 6 and 7 in chronic fatigue syndrome: a case-control study. Clin Infect Dis. (2000) 31:48-52. doi: 10.1086/313908

16. Hickie I, Davenport T, Wakefield D, Vollmer-Conna U, Cameron B, Vernon SD, et al. Post-infective and chronic fatigue syndromes precipitated by viral and non-viral pathogens: prospective cohort study. BMJ. (2006) 333:575. doi: 10.1136/bmj.38933.585764.AE

17. Cameron B, Flamand L, Juwana H, Middeldrop J, Naing Z, Rawlinson W, et al. Serological and virological investigation of the role of the herpesviruses EBV, CMV and HHV-6 in post-infective fatigue syndrome. J Med Virol. (2010) 82:1684-8. doi: 10.1002/jmv.21873

18. Oakes B, Hoagland-Henefield M, Komaroff AL, Erkison JL, Huber BT. Human endogenous retrovirus-K18 superantigen expression and human herpesvirus-6 and human herpesvirus-7 viral loads in chronic fatigue syndrome patients. Clin Infect Dis. (2013) 56:1394-400. doi: 10.1093/cid/cit086

19. Swanink CM, van der Meer JW, Vancoulen JH, Bleijenberg G, Fennis JF, Galama, JM. Epstein-Barr virus (EBV) and the chronic fatigue syndrome: normal virus load in blood and normal immunological reactivity in the EBV regression assay. Clin Infect Dis. (1995) 20:13902. doi: 10.1093/clinids/20.5.1390

20. Kristiansen MS, Stabursvik J, O'Leary C, Pedersen M, Asprusten TT, Leegaard T, et al. Clinical symptoms and markers of disease mechanisms in adolescent chronic fatigue following Epstein-Barr virus infections: an exploratory cross-sectional study. Brain Behav Immun. (2019) 80:55163. doi: 10.1016/j.bbi.2019.04.040

21. Shikova E, Reshkova V, Kumanova A, Raleva S, Alexandrova D, Capo N, et al. Cytomegalovirus, Epstein-Barr virus and human herpesvirus-6 infections in patients with Myalgic encephalomyelitis/chronic fatigue syndrome. J Med Virol. (2020) 1-7. doi: 10.1002/jmv.25744. [Epub ahead of print].

22. Blomberg, J., Rizwan, M., Böhlin-Wiener, A., Elfaitouri, A., Julin, P., Zachrisson, O., et al. Antibodies to human herpesviruses in myalgic encephalomyelitis/chronic fatigue syndrome patients. Front Immunol. (2019) 10:1945. doi: 10.3389/fimmu.2019.01946

23. Vider-Shalit T, Fishbain V, Raffaeli S, Louzoun Y. Phasedependent immune evasion of herpesviruses. J Virol. (2007) 81:9536-45. doi: 10.1128/JVI.02636-06

24. Pellett PE, Roizman B. Herpesviridae. In: Knipe DM, Howley PM, editors. Fields Virology, Vol. 2. 6th ed. Philadelphia, PA: Lippincott Williams \& Wilkins (2013). p. 1802-22.

25. Loebel M, Eckey M, Sotzny F, Hahn E, Bauer S, Grabowski P, et al. Serological profiling of the EBV immune response using a peptide microarray. PLoS ONE. (2017) 12:e0179124. doi: 10.1371/journal.pone.0179124

26. Burbelo PD, Lebovitz, EE, Notkins, AL. Luciferase immunoprecipation systems for measuring antibodies in autoimmune and infectious diseases. Transl Res. (2015) 165:325-35. doi: 10.1016/j.trsl.2014. 08.006

27. Xu GJ, Kula T, Xu Q, Li MZ, Vernon SD, Ndung'u T, et al. Comprehensive serological profiling of human populations using a synthetic human virome. Science. (2015) 348:aaa0698. doi: 10.1126/science.aaa0698 
28. Burbelo PD, Iadarola MJ, Chaturvedi A. Emerging technologies for the detection of viral infections. Future Virol. (2019) 14:39-49. doi: 10.2217/fvl-2018-0145

Conflict of Interest: The author declares that the research was conducted in the absence of any commercial or financial relationships that could be construed as a potential conflict of interest.
Copyright (c) 2020 Ariza. This is an open-access article distributed under the terms of the Creative Commons Attribution License (CC BY). The use, distribution or reproduction in other forums is permitted, provided the original author(s) and the copyright owner(s) are credited and that the original publication in this journal is cited, in accordance with accepted academic practice. No use, distribution or reproduction is permitted which does not comply with these terms. 